Rev. Biol. Trop., 47(3): 411-418, 1999

www.ucr.ac.cr www.ots.ac.cr www.ots.duke.edu

\title{
Reproductive cycle of the bivalve Lima scabra (Pterioida: Limidae) and its association with environmental conditions
}

\author{
César J. Lodeiros ${ }^{1}$ and John H. Himmelman ${ }^{2}$ \\ 1 Departamento de Biología Pesquera, Instituto Oceanográfico de Venezuela, Universidad de Oriente, Cumaná 6101, \\ Venezuela. Fax: 93-315902. E-mail: clodeiro@sucre.udo.edu.ve (corresponding author) \\ 2 Département de Biologie, Université Lav 1, Québec, Canada G1K 7P4
}

Received 26-VI-1998. Corrected 24-II-1999. Accepted 26-II-1999.

\begin{abstract}
We examined the reproductive cycle of a tropical bivalve, the fire scallop Lima (Ctenoides) scabra (Born, 1778), over a 14 months period in the Golfo de Cariaco, Venezuela, and the association of gonadal growth and spawning with environmental factors. Most small individuals were males and most large individuals females, indicating the protandrous characteristic of this species. We documented three marked decreases in gonadal mass, from late October to December 1992, from early June to early July 1993 and from late October to early December 1993, and all were associated with drops in temperature related to renewed upwelling. This suggested that major synchronized spawnings were stimulated by drops in temperature or other factors related to the onset of upwelling. Multiple regression analyses indicated that the major environmental factor associated with increases in gonadal mass was phytoplanktonic food availability. Analyses of regressions of mass of somatic tissues to shell height suggested decreases in reserves in somatic tissues at the end of the NovemberDecember spawnings, but not at the end of the June-July spawning. This may be because body reserves are used for reproduction during November and December when phytoplanktonic food availability is low.
\end{abstract}

Key words: Lima scabra, bivalve, reproduction, environmental conditions, temperature, food availability.

The fire scallop Lima (Ctenoides) scabra (Born, 1778) is found from North Carolina in the United States to the northeastern coast of Brazil (Abbott 1974, Díaz and Puyana 1994). Along the coast of the Golfo de Cariaco, Venezuela, it is common in rocky crevices and spaces among coral branches. Although the biomass of this species can be relatively high $\left(11.3 \mathrm{~g}\right.$ dry mass $/ \mathrm{m}^{2}$ in the Golfo de Cariaco, Gómez et al. 1995), it is not well suited for commercial exploitation because of the difficulty in collecting it from coral habitats. Also, harvesting would likely damage coral communities. It likely has value as an ornamental species for aquaria, because of its beautiful shell with radiating ribs, the long tentacles and the striking red tissues (owing to their high carotenoid con- tent; Lin and Pompa 1977). In fact, it is occasionally collected commercially as an ornamental species in the Golfo de Cariaco (J. Belmonte-Valmore, ACUMAR Srl., Carretera Cumaná-Marigüitar, Venezuela, personal communication).

Few studies have examined the reproductive biology of species in the genus Lima. Two studies by Gómez et al. $(1990,1995)$ report on aspects of the population biology of Lima scabra in the Golfo de Cariaco and indicate it is a protandric hermaphroditic species. No studies have described its reproductive cycle. The present study documents the reproductive cycle over 14 months and at the same time examines the relation between gonadal growth and spawning and environmental factors. 


\section{MATERIALS AND METHODS}

To document the reproductive cycle of $L$. scabra, 30-35 individuals were colleted from amongst coral branches (mainly Diploria strigosa and Millepora alcicornis ) at $0.5-2.5 \mathrm{~m}$ in depth at Turpialito $\left(10^{\circ} 26^{\prime} 56^{\prime \prime} \mathrm{N} ; 64^{\circ} 02^{\prime}\right.$ 00 " W), in the Golfo de Cariaco, Venezuela at 1-2 months intervals from October 1992 through December 1993. The bivalves were removed from crevices using large tweezers. The samples were transported to the laboratory in insulated containers at $\sim 10{ }^{\circ} \mathrm{C}$. For each individual, we measured shell height (dorsal-ventral axis) with an electronic caliper $(0.01$ precision $)$ and then dissected it to separate the gonad, shell, muscle and remaining somatic tissues which were weighed to a $0.001 \mathrm{~g}$ precision (after draining for $5 \mathrm{~min}$ on paper toweling). The sex of the gonad was determined from observations of tissues with a microscope and from gonadal color (brown for females and gray for males).

In examining seasonal changes in gonadal size we used gonadal mass as a percentage of somatic tissue mass (muscle and remaining tissues) as a gonadal index. An ANCOVA using shell height as the covariate indicated that slopes of the relationships of somatic tissue mass, shell mass, and total mass to shell height were similar $(P>0.1)$.

Numerous environmental factors were quantified to evaluate their possible influence on the reproductive cycle of L. scabra. A Sealog electronic thermograph (Vemco Ltd., Halifax, Canada) was placed at $\sim 1 \mathrm{~m}$ in depth among the corals to continuously record temperature.Other variables were determined from water samples taken from $0.5-1 \mathrm{~m}$ in depth with a 5-L Niskin bottle at weekly intervals from a fixed station at the entry to the cove. As soon as the bottles were removed from the water, samples were taken for oxygen determinations (Winkler method, Strickland and Parsons 1972). We also took 400 $\mathrm{mL}$ samples for salinity determinations (using an inductive salinometer and the cal- culations described by Anomymous 1981) and $500 \mathrm{~mL}$ samples were preserved in $10 \%$ formaldehyde for phytoplankton identifications and counts. The remaining water was transferred to the laboratory in opaque containers for the analysis of seston. Within $2 \mathrm{~h}$ in the laboratory, we removed macroplankton using $153-\mu \mathrm{m}$ Nytex screens and then 500 or $1000 \mathrm{~mL}$ aliquots were passed through 0.7$\mu \mathrm{m}$ fiberglass MFSF filters. These samples were frozen at $-20{ }^{\circ} \mathrm{C}$ for subsequent analyses. The masses of organic and inorganic seston were measured gravimetrically and chlorophyll $a$ was determined using the spectrophotometic method as described by Strickland and Parsons (1972). The energetic content of the seston was estimated from measurements of protein (Lowry et al. 1951) and carbohydrate (Dubois et al. 1956) content, using conversion factors of 23.9 and $17.5 \mathrm{KJ} \mathrm{g}^{-1}$, respectively (Gnaiger and Bitterlich 1984). After permitting the phytoplankton to settle using Utermöhl's technique (1958), we identified and counted the species present using an inverted microscope. Low magnification (10X objective) was used for macrophytoplankton and high magnification (40X) for micro- and nano-plankton. In the analysis, the phytoplankton was separated into four groups, diatoms, dinoflagellates, cocolithophores and nanoflagellates $(<20 \mu \mathrm{m}$; we did not distinguish between auto- and heterotrophic flagellates).

To evaluate the effect of environmental factors on the gonadal development of $L$. scabra, we examined the relation between increases in the gonadal index and environmental conditions (the mean values during each period of gonadal increase) using a stepwise multiple regression analysis $(P=0.05)$ applied to log-transformed data. All of the recorded environmental parameters were considered. Colinearity effects within predictive models must be minimized (Hair et al. 1992) and Pearson Correlation Analyses indicated that the correlations among variables were not high $(\mathrm{r}<0.7)$. 


\section{RESULTS}

On most sampling dates, gonadal indices were highly variable suggesting varying stages of gonadal development (Fig. 1). The similar range of the gonadal indices for small to large individuals indicated that all sizes sampled, from 25 to $75 \mathrm{~mm}$ in shell height, were reproductively active. However, during the period from $15 \mathrm{De}-$ cember 1992 to 1 March 1993 and on 6 July
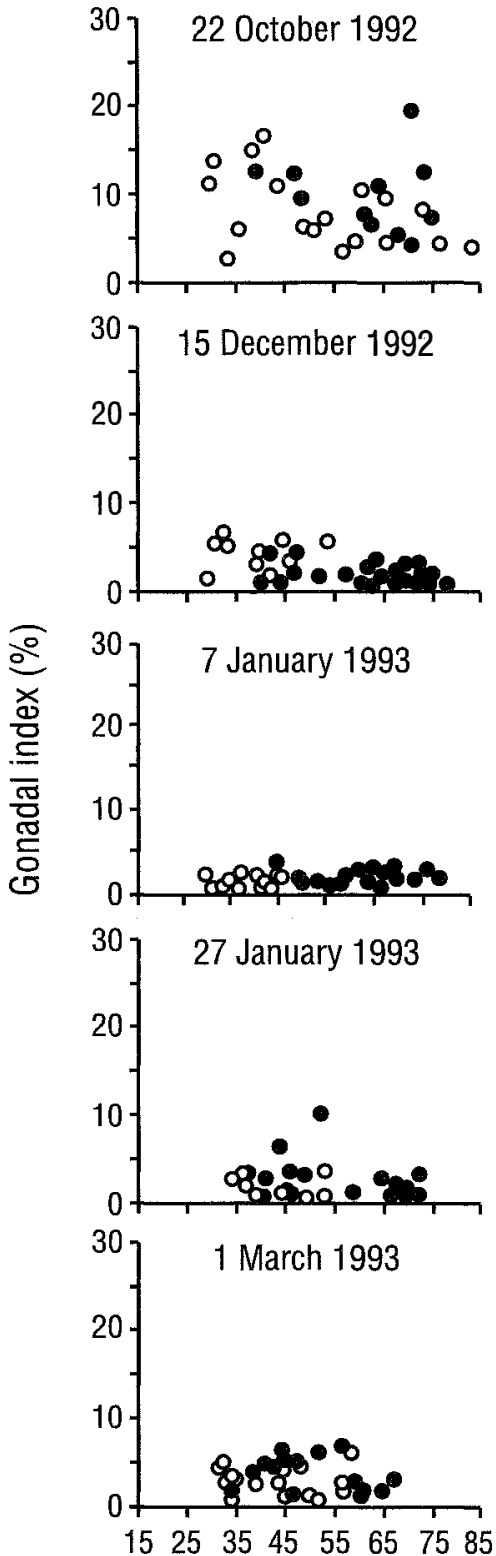

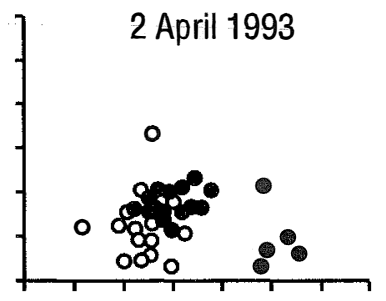

2 May 1993
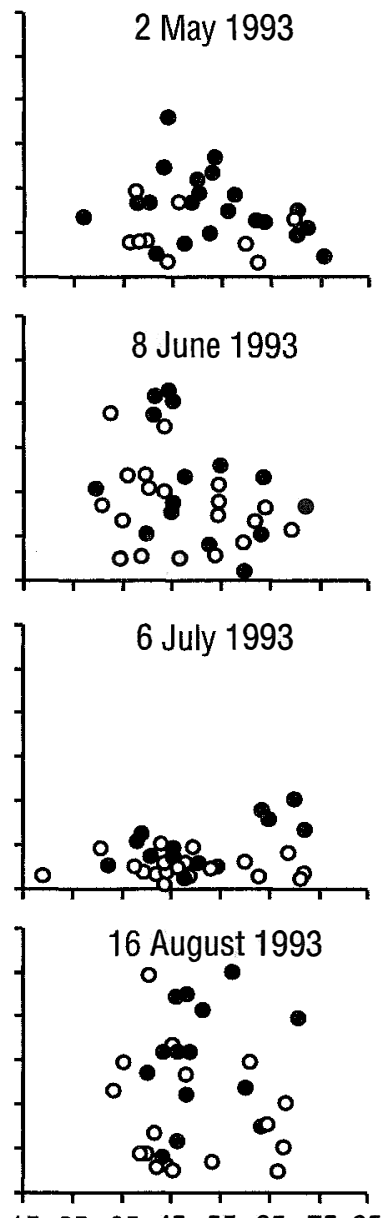

$15253545 \quad 55657585$
- Males

- Females
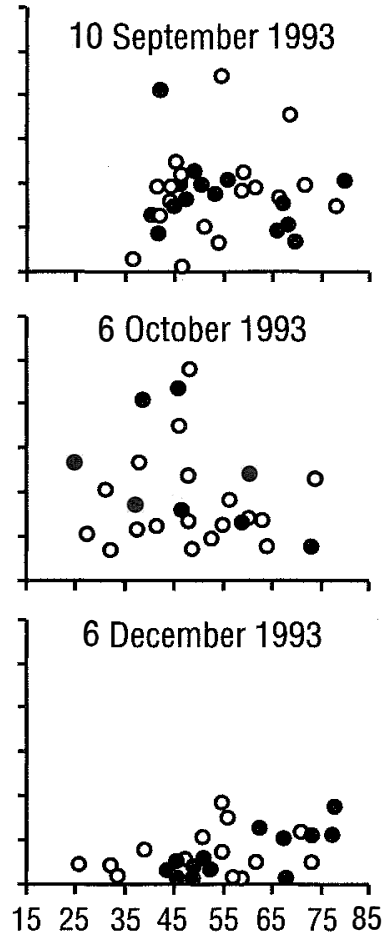

Shell Height $(\mathrm{mm})$

Fig. 1. Lima scabra. Relation of testicular and ovarian indices to shell height for individuals collected at Turpialito on different dates from November 1992 to December 1993. 
1993 and 6 December 1993 indices were consistently low (generally $<5 \%$, Fig. 1 ) and testes and ovaries were translucent and flaccid suggesting they were in spent condition.

The mean testicular and ovarian indices showed decreases during the first sampling dates, from late October to December 1992, suggesting a synchronized spawning (Fig. 2). Then the indices increased almost steadily until 8 June 1993, after which a second decrease occurred by 6 July 1993. Following this, a rapid gonadal growth occurred to a peak in late August. High levels were sustained until 6 October and then a third decrease occurred by early December 1993. Thus, $L$. scabra appears to have two major spawnings per year, one from June to early July and a second from November to December. Although the pattern was almost the same for both sexes, ovarian mass was greater than testicular mass (paired Student t-test, $P<0.001$ ). The proportion of females increased with shell height which is indicative of a protandric species (Fig. 3).

For muscle and remaining somatic tissues, the intercept on the $\mathrm{Y}$ axis for regressions of tissue mass to shell height showed no marked variations over time $(a=1.62-1.85$ for muscle and $a=1.38-1.59$ for remaining tissues, Table 1). Also, the regression slopes did not vary between males and females on any sampling date, except for remaining somatic tissue mass in January 1993 and muscle mass

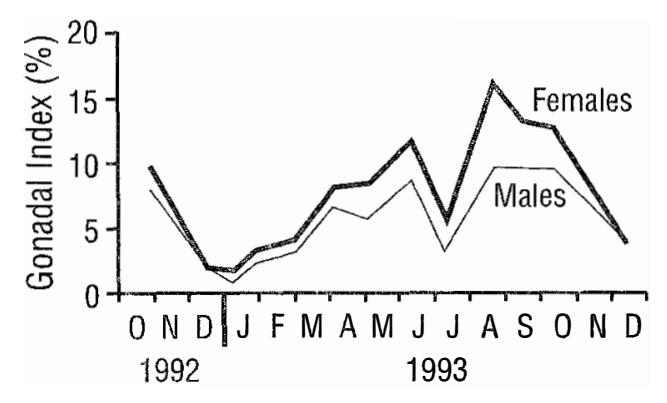

Fig. 2. Lima scabra. Mean testicular and ovarian indices for individuals collected at Turpialito at 1-2 month intervals from November 1992 to December 1993. in August 1993 (Student t-tests of slopes, $P<0.05)$. The similarity in slopes may indicate that the quantity of reserves in the somatic tissues, and possibly physiological condition, was generally similar for the two sexes. For both males and females, the slopes of mass of the muscle and remaining somatic tissues to shell height tended to be lower on 7 January 1993 and 6 December 1993, when the animals were in post spawning condition, than prior to spawning, 22 October 1992 and 6 October 1993, respectively $(P<0.05)$, suggesting that these spawnings caused a depletion of tissue reserves.

The stepwise multiple regression models indicated that environmental factors could in large part predict gonadal growth (Males = 2.77 chlorophyll $a+1.05$ seston energy + $0.77, \mathrm{r}^{2}=0.51, P<0.017$ : females $=5.25$ chlorophyll $a+0.39$ nanoflagellates +3.67 oxygen $\left.+7.75, \mathrm{r}^{2} 0.82, P<0.002\right)$. Chlorophyll $a$ was the first factor integrated into the models for both males and females indicating that the phytoplanktonic biomass was the principally factor influencing gonadal growth. Temperature did not appear to be critical for gonadal growth, as it was not retained in the regression models. Nevertheless, temperature may have had an effect on spawning as each of the three major spawning events were associated with a temperature decrease (Fig. 4).

\section{DISCUSSION}

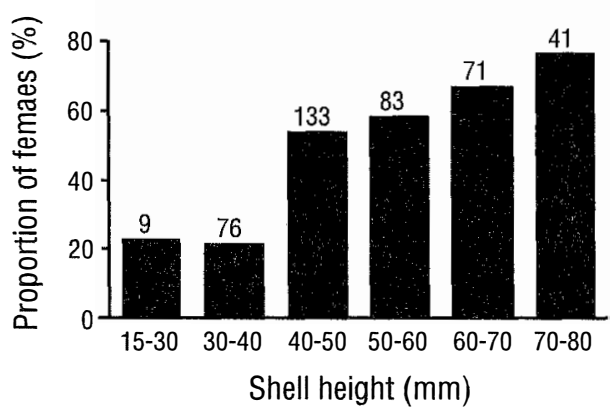

Fig. 3. Lima scabra. Percentage of females in relation to shell height. Numbers above the bars indicate the numbers of scallops sampled for each size class. 


\section{TABLE 1}

Regression relationships between somatic tissues (muscle and remaining somatic tissues) and shell height for male and female Lima scabra collected on different dates between October 1992 and December 1993 t Turpialito in the Golfo de Cariaco, Venezuela

\begin{tabular}{|c|c|c|c|c|c|c|c|}
\hline \multirow[b]{2}{*}{ Date } & & \multicolumn{3}{|c|}{ Muscle } & \multicolumn{3}{|c|}{ Remaining somatic tissue } \\
\hline & & a & b & $\mathrm{r} 2$ & a & $\mathrm{b}$ & $\mathrm{r} 2$ \\
\hline \multirow[t]{2}{*}{$28-10-92$} & Male & 1.70 & 0.27 & 0.77 & 1.56 & 0.26 & 0.87 \\
\hline & Female & 1.73 & 0.26 & 0.93 & 1.55 & 0.31 & 0.91 \\
\hline \multirow[t]{2}{*}{$15-12-92$} & Male & 1.71 & 0.32 & 0.87 & 1.52 & 0.38 & 0.97 \\
\hline & Female & 1.75 & 0.27 & 0.75 & 1.57 & 0.32 & 0.90 \\
\hline \multirow[t]{2}{*}{$07-01-93$} & Male & 1.67 & 0.19 & 0.65 & 1.55 & 0.23 & 0.78 \\
\hline & Female & 1.76 & 0.20 & 0.69 & 1.60 & 0.26 & 0.80 \\
\hline \multirow[t]{2}{*}{$27-01-93$} & Male & 1.67 & 0.27 & 0.57 & 1.50 & 0.32 & 0.82 \\
\hline & Female & 1.70 & 0.31 & 0.90 & 1.59 & 0.24 & 0.78 \\
\hline \multirow[t]{2}{*}{ 01-03-93 } & Male & 1.63 & 0.30 & 0.92 & 1.45 & 0.38 & 0.93 \\
\hline & Female & 1.66 & 0.30 & 0.83 & 1.48 & 0.36 & 0.85 \\
\hline \multirow[t]{2}{*}{ 02-04-93 } & Male & 1.63 & 0.26 & 0.73 & 1.50 & 0.28 & 0.77 \\
\hline & Female & 1.64 & 0.32 & 0.94 & 1.47 & 0.37 & 0.95 \\
\hline \multirow[t]{2}{*}{$02-05-93$} & Male & 1.64 & 0.27 & 0.97 & 1.51 & 0.31 & 0.98 \\
\hline & Female & 1.66 & 0.30 & 0.92 & 1.54 & 0.27 & 0.84 \\
\hline \multirow[t]{2}{*}{$08-06-93$} & Male & 1.67 & 0.30 & 0.92 & 1.50 & 0.33 & 0.92 \\
\hline & Female & 1.67 & 0.29 & 0.81 & 1.46 & 0.42 & 0.88 \\
\hline \multirow[t]{2}{*}{$06-07-93$} & Male & 1.67 & 0.30 & 0.92 & 1.51 & 0.33 & 0.93 \\
\hline & Female & 1.67 & 0.34 & 0.94 & 1.52 & 0.31 & 0.98 \\
\hline \multirow[t]{2}{*}{$16-08-93$} & Male & 1.66 & 0.32 & 0.89 & 1.48 & 0.37 & 0.97 \\
\hline & Female & 1.69 & 0.19 & 0.80 & 1.50 & 0.31 & 0.89 \\
\hline \multirow[t]{2}{*}{$10-09-93$} & Male & 1.67 & 0.26 & 0.70 & 1.49 & 0.34 & 0.94 \\
\hline & Female & 1.68 & 0.26 & 0.70 & 1.49 & 0.34 & 0.79 \\
\hline \multirow[t]{2}{*}{ 06-10-93 } & Male & 1.62 & 0.40 & 0.86 & 1.38 & 0.44 & 0.97 \\
\hline & Female & 1.66 & 0.47 & 0.88 & 1.38 & 0.51 & 0.95 \\
\hline \multirow[t]{2}{*}{$06-12-93$} & Male & 1.85 & 0.34 & 0.98 & 1.51 & 0.35 & 0.99 \\
\hline & Female & 1.67 & 0.27 & 0.63 & 1.51 & 0.33 & 0.95 \\
\hline
\end{tabular}

The parameters $a$ and $b$ correspond to the regression equation of the form $a+b X$ and $r^{2}$ is the coeficient of determination. All regresions were signifiant with a $\mathrm{P}<0.006$.

We observed $25-30 \mathrm{~mm} \mathrm{L.} \mathrm{scabra} \mathrm{with}$ testes in all stages of development, from developing to spent, suggesting that individuals of this size reproduce. That most small individuals were males and most large individuals females corroborates the protandrous characteristic of $L$. scabra as reported by Gómez et al.
(1990, 1995). Separating production of spermatozoa and ovules over time in dioique species may serve as a mechanisms to prevent self fertilization. That $L$. scabra usually occurs in aggregations amongst coral branches should enhance fertilization success. An alternative hypothesis for prodrandric hermadrophism is 

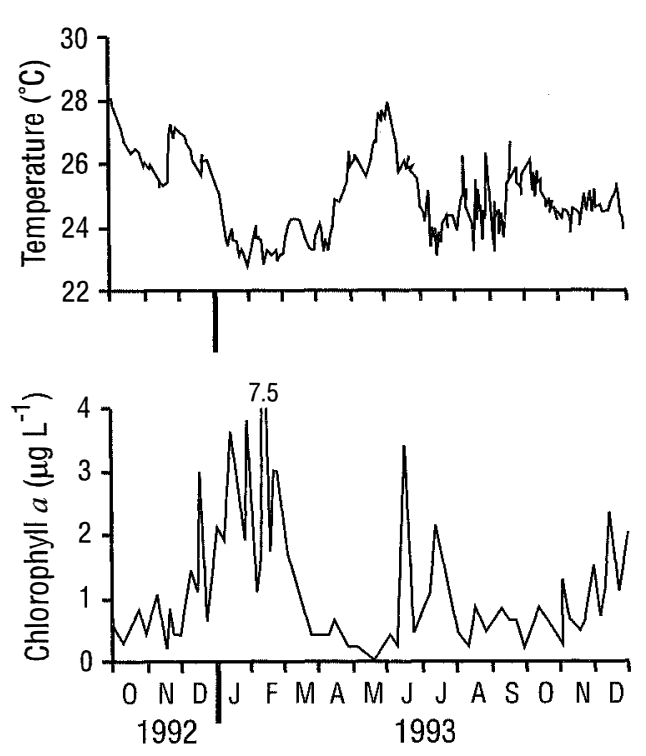

Fig. 4. Seasonal changes in temperature and chiorophyll a concentration from October 1992 to December 1993 at the study area at Turpialito in the Golfo de Cariaco, Venezuela.

that it permits an initial period of more rapid somatic growth, because of a lower energetic cost of producing spermatozoa compared to ovules. However, the similar slopes for male and female $L$. scabra in regressions of somatic tissues to shell height suggested that the costs of producing male and female gametes were similar. Studies monitoring the developing of marked individuals over time are required to further elucidate the prodrandous gonadal development of $L$. scabra.

Our data on gonadal size indicates highly variable gonadal development during most of the year but at certain periods most individuals have small spend gonads. This suggests that $L$. scabra undergoes partial spawnings throughout much of the year and more massive and synchronized spawnings at other times. The more massive spawnings may be coordinated by an external cue. The association of the three marked decreases in gonadal mass with drops in temperature in our study indicates that temperature decreases, or other factors related to upwelling, may provoke spawning. Gómez et al. (1995) reports high recruitment of juveniles between January to April, 1-2 mo after the November to December spawning observed in our study. Recruitment, juvenile growth and survival may be enhanced during January to April as this period corresponds to a period of strong upwelling and low temperatures in our study region (Mandelli and Ferraz-Reyes 1982, Lodeiros and Himmelman 1994, Lodeiros 1996).

Many studies consider temperature as an important factor for both gametogenesis and spawning in marine invertebrates (Loosanoff and Davis 1963, Giese and Pearse, 1974, Sastry 1979, Giese and Kanatami 1987, Barber and Blake 1991). However, the association of massive spawnings of $L$. scabra with drops in temperature contrasts with most bivalves for which spawning is associated with temperature increases (Sastry 1979, Giese and Kanatami 1987). Bivalves in the Golfo de Cariaco apparently have various reproductive strategies, as Nodipecten nodosus (Vélez et al. 1987) and Pteria colymbus (Marquez 1996, Lodeiros et al. 1997) spawn throughout the year, without showing any relationship to temperature, and Euvola ziczac (Vélez et al., 1993, Lodeiros and Himmelman 1994) spawns during temperature peaks. The mussel Perna perna (Vélez and Epifanio 1981) is the only other species in northeastern Venezuela for which spawning is suggested to be associated with temperature decreases.

The multiple regression analyses indicated that the primary environmental factor influencing gonadal growth is chlorophyll $a$ concentration, suggesting that production of gametes is stimulated by increases in phytoplankton. Phytopanktonic food availability is also indicated as a major determinant of gonadal development in a number of other bivalves (Sastry 1979, Giese and Kanatami 1987, Barber and Blake 1991).

The analyses of regression slopes for the relationships of the mass of somatic tissues to shell height for $L$. scabra (Table 1) suggested a reduction of energetic reserves in the somatic tissues during the sharp gonadal decreases during November and December 1992 and October and November 1993. In the Golfo de Cariaco, a drop 
in wind velocities, generally from August-September to November-December, causes a stratification of the water column and decreased primary production as evidenced by reduced chlorophyll $a$ levels (Mandelli and Ferraz-Reyes 1982, Ferraz-Reyes 1989, Quintero and Lodeiros 1996, Lodeiros and Himmelman 1994, Lodeiros 1996, present study). The decreased food availability associated with the period of gonadal peak and spawning could explain the low level of reserves after spawning. In contrast, no change in regression slopes (which might indicate a depletion of reserves) was detected during the June and July 1993 spawning. This is likely because the second spawning period was preceded by a period of abundant phytoplanktonic food (Fig. 5), related to upwelling conditions. Histological studies of the gonadal, energetic determinations of the different tissues, and labeling studies are needed to evaluate whether somatic tissue reserves are only used for gamete production when phytoplanktonic food availability is low.

The present study indicates that gonadal growth of $L$. scabra in the Golfo de Cariaco is strongly linked to increased phytoplanktonic food availability. In this area, increases in phytoplankton production resulting from upwelling of nutrient-rich deeper water brought about by strong and continuous northeast winds. This upwelling causes a breakdown of the thermocline and abrupt drop in temperature. The major spawnings are associated with the initiation of upwelling and thus may be stimulated by the drop in temperature or other upwelling related factors. The increased primary production following such spawnings may be advantageous as a food source for the larvae or recruiting individuals.

\section{ACKNOWLEDGMENTS}

We are grateful to E. Marcano, R. Espinoza, F. Morales, J. Rengel, D. Hernández, A. Marquez and P. Nuñez for their aid in analyzing the samples, and A. Prieto for his critical reading of the paper.

\section{REFERENCES}

Abbott, R.T. 1974. American seashells. Van Nostrand Reinhold, New York. 663 p.

Anomymous. 1981. Tenth report of the joint panel on oceanographic tables and standards. UNESCO Tech. Pap. Mar. Sci. No. 36.

Barber, B.J. \& N.J. Blake. 1991. Reproductive physiology, p. 377-428. In S.E. Shumway (ed.). Scallops: biology, ecology and aquaculture. Developments in Aquaculture and Fisheries Science Vol. 21, Elsevier Science, New York.

Díaz, J.M. \& M. Puyana. 1994. Moluscos del Caribe Colombiano. Un catálogo Ilustrado. COLCIENCIAS, Fundación Natura and INVEMAR, Bogotá. 367 p.

Dubois, M., J. Giles, J. Hamamilton, P. Reber \& F. Smith. 1956. Colorimetric method for determination of sugars and related substances. Anal. Chem. 28: 2350-2356.

Ferraz-Reyes, E. 1989. Influencia de los factores fisícos en la distribución vertical de la biomasa fitoplanctónica, en el Golfo de Cariaco (Venezuela). Bol. Inst. Oceanogr. Univ. Oriente 28: 47-56.

Giese, A. C. \& J.S. Pearse. 1974. Introduction: general principles, p. 1-49. In A.C. Giese \& J.S. Pearse, (eds.). Reproduction of marine invertebrates, Vol I. Academic, New York.

Giese,A A. C. \& H. Kanatani. 1987. Maturation and spawning, p. 251-329. In A.C. Giese, J. Pearse \& V. Pearse (eds.). Reproduction of marine invertebrates, Vol. $\mathbf{X}$, Blacwell Scientific and Boxwood, San Diego.

Gnaiger, E. \& G. Bitterlich. 1984. Proximate biochemical composition and caloric content calculated from elemental CHN analysis: a stoichiometric concept. Oecologia 62: 289-298.

Gómez, J., A. Prieto. \& C. Lodeiros. 1990. Relaciones biométricas y biomasa específica en el bivalvo Lima scabra tenera (Sowerby, 1843). Scientia (Panamá) 5: 13-17.

Gómez, J., I. Liñero \& J. Fermín. 1995. Estudios ecológicos sobre Lima scabra (Born, 1778) (Pelecipoda: Limidae) en el Golfo de Cariaco, Venezuela. I.- Censo y relaciones morfométricas. Bol. Inst. Oceanogr. Univ. Oriente 34: 109-120.

Hair, J.F., R.E. Anderson, L.R. Tatham. \& W.C. Black. 1992. Multivariate data analysis with regarding. MacMillan, New York. 544 p. 
Lin, A. L.\& L.A. Pompa. 1977. Carotenoids of the red clam Lima scabra. Bol. Inst. Oceanogr. Univ. Oriente 16: 83-86.

Lodeiros C. J. 1996. Influence des facteurs environnementaux sur la croissance du pétoncle tropical Euvola (Pecten) ziczac (L. 1758) cultivé en suspension au Golfo de Cariaco, Vénézuela. Ph.D. Thesis, Department of Biology, Laval University. Québec, Canada. 83 p.

Lodeiros, C.J. \& J.H. Himmelman. 1994. Relations among environmental conditions and growth in the tropical scallop Euvola (Pecten) ziczac (L.) in suspended culture in the Golfo de Cariaco, Venezuela. Aquaculture 119: 345-358.

Lodeiros, C.J., B. Marquez \& M. Jimenez. 1997. The Atlantic winged oyster Pteria colymbus (Röding, 1798), a potential species for culture in Venezuela: collection and growth. Islands Aquaculture and Tropical Aquaculture, Les Trois Ilets, Martinique 1997. 4 p.

Loosanoff, V. \& H. Davis. 1963. Rearing of bivalve molluscs. Adv. Mar. Biol. 1: 1-136.

Lowry, O., N. Rosebbrouch, A. Farr \& R. Randall. 1951. Protein measurement with the Folin phenol reagent. J. Biol. Chem. 193: 265-275.

Mandelli, E. \& E. Ferraz-Reyes. 1982. Primary production and phytoplankton dynamics in a tropical inlet, Gulf of Cariaco, Venezuela. Inst. Revue ges. Hydrobiol. 67: 85-95.

Marquez, B. 1996. Variación estacional de la fijación de la ostra negra Pteria colymbus (Röding, 1798) (Bivalvia:
Pteriidae) a diferentes profundidades en la localidad de Turpialito, Golfo de Cariaco, Edo. Sucre, Venezuela. Licenciatura thesis, Departamento de Biología, Universidad de Oriente, Cumaná, Venezuela. 69 p.

Quintero, A. \& C. Lodeiros. 1996. Variaciones térmicas del agua en Turpialito, Golfo de Cariaco, Venezuela. Bol. Inst. Oceanogr. Univ. Oriente 35: 27-40

Sastry, A.N. 1979. Pelecipoda (excluding Ostreidae), p. 113-292. In A.C. Giese \& J.S. Pearse (eds.). Reproduction of marine invertebrates. Vol. V, Academic, New York.

Strickland, J.D.H. \& T.R. Parsons. 1972. A practical handbook of seawater analysis. Bull. Fish. Res. Board Can. No. 167. 310 p.

Utermöhl, H. 1958. Zur Vervollkommnung der quantitativen phytoplankton-methodik. Mitt. int. Verein. theor. angew. Limnol. 9: 1-38.

Vélez, A., F. Sotillo \& J. Pérez. 1987. Variación estacional de la composición química de los pectínidos Pecten ziczac y Lyropecten nodosus. Bol. Inst. Oceanogr. Univ. Oriente 26: 67-72.

Vélez, A. \& C.E. Epifanio. 1981. Effects of temperature and ration on gametogenesis and growth in the tropical mussel Perna perna L. Aquaculture 22: 21-26.

Vélez, A., E. Alifa \& L. Freites. 1993. Inducción de la reproducción en la vieira Pecten ziczac. - I. Maduración y desove. Caribb. J. Sci. 29: 209-213. 